Schulich School of Law, Dalhousie University

Schulich Law Scholars

Research Papers, Working Papers, Conference

Papers

Faculty Scholarship

6-4-2009

\title{
Pitfalls in Patenting Publicly Funded Research - Comments on Draft South African Regulations
}

Cynthia M. M. Ho

Loyola University of Chicago - School of Law - Faculty, cho@luc.edu

Matthew Herder

Dalhousie University, matthew.herder@dal.ca

Follow this and additional works at: https://digitalcommons.schulichlaw.dal.ca/working_papers

Part of the Health Law and Policy Commons, and the Intellectual Property Law Commons

\section{Recommended Citation}

Matthew Herder, "Pitfalls in Patenting Publicly Funded Research - Comments on Draft South African Regulations" (2009) Dalhousie University Schulich School of Law Working Paper No 29.

This Working Paper is brought to you for free and open access by the Faculty Scholarship at Schulich Law Scholars. It has been accepted for inclusion in Research Papers, Working Papers, Conference Papers by an authorized administrator of Schulich Law Scholars. For more information, please contact hannah.steeves@dal.ca. 


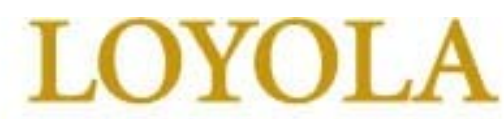

UNIVERSITY CHICAGO

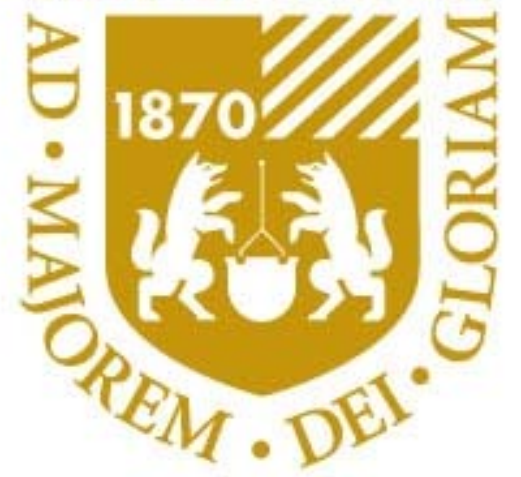

SCHOOL of LAW

A proud heritage...an ambitious future

\section{LOYOLA UNIVERSITY CHICAGO SCHOOL OF LAW}

LOYOLA UNIVERSITY CHICAGO SCHOOL OF LAW

Public LAW \& Legal TheORY Research PAPER No. 2009-010

\section{Pitfalls in PATENTING PUBlicly Funded RESEARCH - COMMENTS ON DRAFT SOUTH AFRICAN REGULATIONS MATTHEW HERDER \& CYNTHIA M. HO}


May 29, 2009

\author{
VIA ELECTRONIC MAIL \\ Department of Science and Technology \\ Attention: Tsitso Daniel Rasenyalo \\ Buuilding 53, CSIR Campus \\ 627 Meiring Naude Road \\ Brummeria \\ Pretoria, 0184
}

\title{
Re: Draft Intellectual Property Rights from Publicly Funded Research and Development Regulations
}

\section{Dear Sir:}

We are writing to provide our comments on the draft Intellectual Property Rights from Publicly Financed Research and Development Regulations (the "Draft Regulations"), proposed for enactment pursuant to the Intellectual Property Rights from Publicly Financed Research and Development Act, 2008 (the "Act”).

As academics researchers with particular expertise in patent law and policy, we have a strong interest in the issues encompassed by the Draft Regulations. Matthew Herder is a Visiting Professor of Law at Loyola University Chicago with expertise relating to patenting and licensing of early-stage research, especially in the life sciences. Cynthia Ho is the Vickrey Research Professor at Loyola University Chicago School of Law, where she writes and teaches on patent law issues, including those involved with the Bayh-Dole Act. We write to you, not in support of a partisan position, but rather in the hope that our knowledge will help in developing optimal regulations.

We do, however, think it is important to underscore what we consider to be the main thrust of the concerns raised by one group, Universities Allied for Essential Medicines (UAEM), in a letter dated May 7, 2009. As UAEM highlighted, the enactment of the Bayh-Dole Act in the United States appears to have led many academic institutions to focus unduly upon patenting and licensing basic scientific discoveries notwithstanding that those activities very seldom generate significant financial returns. Moreover, there is evidence that increases in patenting, and related activity such as licensing, industrysponsored research agreements and the use of materials transfer agreements, can 
negatively impact the flow of knowledge between academic researchers and also impede the public's ability to access technologies such as a diagnostic test. ${ }^{1}$ We therefore contend, like UAEM, that those involved in implementing and administering the Act, especially those individuals who come to make up the National Intellectual Property Management Office (NIPMO), remain mindful of these concerns.

That said, we understand that the issue at this stage is no longer whether to enact legislation similar to the Bayh-Dole Act. ${ }^{2}$ Accordingly, we focus our comments upon the scope and details of the Draft Regulations as they have been proposed. Our comments are divided into two parts. First, we explain our three main concerns with the Draft Regulations. Second, we set out what revisions to the Draft Regulations would help address our concerns.

\section{A. Our Concerns}

We have three primary concerns with the Draft Regulations. Each concern is discussed in depth below.

\section{Failing to allow for timely knowledge dissemination}

We believe one strength of the Act is that it expressly recognizes a funding recipient's right to choose not to seek intellectual property protection (Act, s. 4(2)). ${ }^{3}$ However, this choice must be exercised in accordance with the regulations (Act, s. 4(2)(a)). The Draft Regulations mandate that the NIPMO review the recipient's decision and consider whether to seek IP protection on the State's behalf (Reg. 2(3)-2(6)). Our first primary concern, then, is that the mandatory process will significantly delay dissemination of knowledge to the South African and global research community.

The timeframe set up by the Act and Draft Regulations breaks down as follows. The Act provides that any potentially patentable invention be disclosed to a funding recipient by a researcher within 90 days of its discovery (s. 5(1)(c)). Once disclosure has occurred, the recipient (through its technology transfer office (TTO) or regional TTO) has 30 days to

\footnotetext{
${ }^{1}$ See Eric G. Campbell et al., Data Withholding in Academic Genetics: Evidence from a National Survey, 287 JAMA 473 (2002); D. Blumenthal et al., Data withholding in genetics and other life sciences: prevalences and predictors, 81:2 Acad. Med. 137 (2006); Kenneth G. Huang \& Fiona E. Murray, Does Patent Strategy Shape the Long-Run Supply of Public Knowledge? Evidence from Human Genetics Academy of Management Journal, 40, 42 (forthcoming), available at http://ssrn.com/abstract=1249522; Mildred K. Cho, et al., Effects of Patents and Licenses on the Provision of Clinical Genetic Testing Services, 5 J. Molecular Diagnostics 3, 5 (2003); Jon F. Merz, et al., Industry Opposes Genomic Legislation, 20 NATURE BIOTECHNOLOGY 657 (2002). Also, there is growing recognition that patents may pose access issues to researchers and potential consumers beyond the more limited situation of federally funded research. See, e.g., Lab. Corp. of Am. Holdings v. Metabolite Lab., Inc., 548 U.S. 124 (2006), per Breyer J.; Aaron S. Kesselheim \& Michelle M. Mello, Medical-Process Patents - Monopolizing the Delivery of Health Care, 355 N ENG. J. MED. 2036 (2006).

${ }^{3}$ Note that the choice conferred by s. $4(2)$ is actually broader that this: the provision allows a recipient to choose "not to retain ownership in its intellectual property or not to obtain statutory protection for the intellectual property." Our focus, however, is on the second aspect only.
} 
decide whether to seek patent protection (s. 5(1)(e)). If the decision not to seek patent protection is made, the disclosure must be referred to NIPMO for review unless the disclosure is judged to be "not protectable" (Reg. 2(2)). That is, if the recipient chooses not to seek patent protection for "reasons other than lack of patentability," (Reg. 2(3)) then NIPMO is entitled to review that decision over a period of 60 days taking into account a variety of considerations (Reg. 2(5)-2(6)). If NIPMO decides to seek patent protection, it can either "request the recipient assignment to execute such documents as may be required to effect such assignment of the intellectual property within 30 days" (Reg. 2(7)), or "offer an option to acquire the intellectual property" to any private entity that funded some portion of the research or to the "intellectual property creators" within the same timeframe (Reg. 2(11)). In total, this process could span up to 210 days. And, if NIPMO decides to file a patent application, there will be further delay in disseminating information due to the inevitable time in drafting the application, ${ }^{4}$ and the need to keep the information secret before the application is filed ${ }^{5}$ to avoid losing patent rights entirely under South African law. ${ }^{6}$ A graphic depiction of the total potential delay before knowledge dissemination appears below:

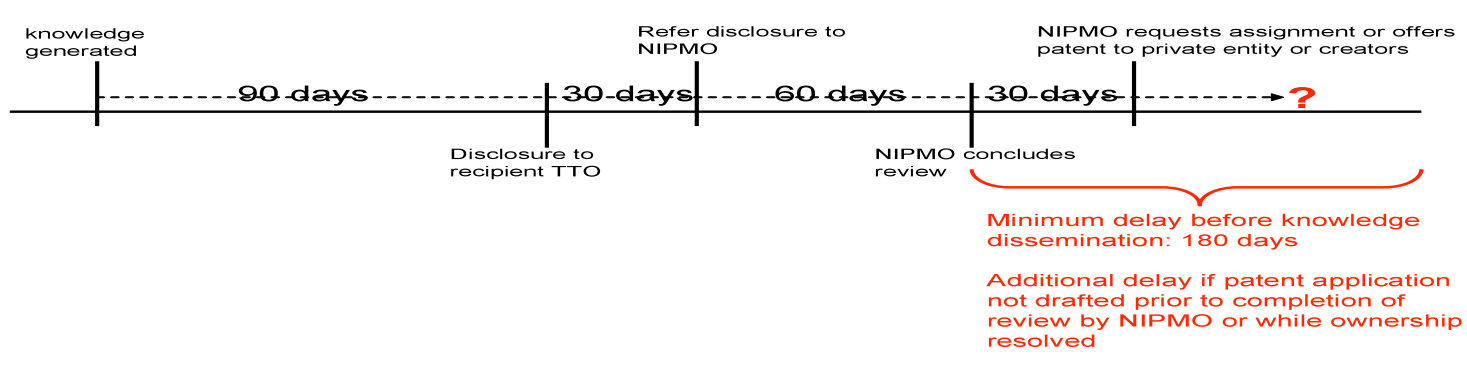

Figure 1. Delay of knowledge dissemination under the Draft Regulations.

In our view, this delay is far too long in one particular set of circumstances: when the recipient chooses not to seek patent protection in respect of knowledge generated in the

\footnotetext{
${ }^{4}$ The Draft Regulations state only that NIPMO must arrive at a decision and inform the recipient of same within 60 days; given that it is not possible to obtain a patent within such a period, we presume that NIPMO is not necessarily expected to file a patent application within that timeframe.

${ }^{5}$ The Act requires recipients of government funding to take steps to protect any potential intellectual property before any results of research are published or otherwise publicly disclosed (s. 5(1)(b)).

${ }^{6}$ Under South African law any public disclosure of an invention renders it non-patentable. In addition, this is also true in most jurisdictions, except for the United States, which currently provides a one year grace period to file a patent application following public disclosure of an invention. See 35 U.S.C. $\$ 102$. However, even with the grace period, some worry that research findings are being kept confidential for too long, particularly in the life sciences, while universities (often in conjunction with private firms that are potential licensees) decide whether to file a patent application. In the context of industry-sponsored university research, publication delays between three to six months (or 90-180 days) have become standard practice. See, for e.g., Campbell et al., supra.
} 
course of research, not because it has no future commercial value or because it may not be patentable, but because of its immediate value to the research community as a foundational discovery, research tool, or platform technology. The researchers responsible for generating this knowledge are in the best position to identify knowledge falling into that category because they are part and parcel of the pertinent research community; as active participants in this community they - rather than the TTO or the NIPMO - are, by definition, in the best position to make this determination. Yet unless the knowledge is considered "not protectable," these same researchers are required to wait approximately six months before they can share that knowledge with other researchers and institutions. ${ }^{7}$

\section{Providing greater guidance with respect to patenting and licensing practices, including guidance for when patenting is inappropriate}

Our second main concern is that the Draft Regulations could provide more guidance to publicly funded research institutions with respect to patenting and licensing practices, including when to forego patenting and what rights to reserve when licensing inventions. We commend the Draft Regulations for granting NIPMO the authority to develop "appropriate standards and best practices in consultation" with funding recipients under the Act (s. 9(3)(d)). However, we recommend immediate inclusion of two best practices that have emerged from years of experience under the Bayh-Dole Act in the United States and similar legal frameworks in a variety of other countries.

First, related to our first concern above, the Draft Regulations should explicitly state that patenting may not be appropriate when "significant further research and development investment is not required" 8 or when the knowledge in question is considered "fundamental" to a field of scientific inquiry. ${ }^{9}$ These two categories can overlap: they are both capable of capturing research materials and research tools. Nevertheless, we contend that the Draft Regulations should spell out both sets of circumstances in order to (1) provide recipients with greater flexibility, and (2) underscore the notion that even if those materials and tools are expected to be lead to more applied technologies, which will in turn require subsequent investments and thus necessitate patent protection, the fundamental discoveries themselves should not be patented. We provide specific language to incorporate these best practices in the next section.

Second, while we applaud the Draft Regulations for setting out a variety of conditions that must be included in a variety of licenses, we believe that one additional condition should be mandatory for all licenses, whether domestic or offshore, exclusive or nonexclusive. ${ }^{10}$ Specifically, recipients should, in all cases, retain the right to utilize an

\footnotetext{
${ }^{7}$ Conceivably, as presently worded, these same researchers could even be offered ownership of any patent that NIPMO elects to prosecute (pursuant to Reg. 2(11)(b)) despite their original intentions to the contrary.

${ }^{8}$ See National Institutes of Health, Best Practices for the Licensing of Genomic Inventions (2005), http://ott.od.nih.gov/pdfs/70FR18413.pdf.

${ }^{9}$ See Arti K. Rai \& Rebecca S. Eisenberg, Bayh-Dole Reform and the Progress of Biomedicine, 66 L. \& CONT. PROBS. 289 (2003), discussing several examples of fundamental discoveries.

${ }^{10}$ Currently under Draft Regulation 8(1), recipients have "sole discretion" to determine the terms and conditions of any non-exclusive license. This would need to be changed if our recommendation is adopted.
} 
invention for basic research and educational purposes as well the right to permit other "higher education institutions" (as contemplated by the Act, s. 1) in the Republic to do the same. This practice has been recommended by the National Institutes of Health, ${ }^{11}$ the Organisation for Economic Co-operation and Development, ${ }^{12}$ and leading officials in the technology transfer community in the United States. ${ }^{13}$

\section{Preserving the Act's intention of protecting the State's ability to use any resulting intellectual property in the service of its "health, security and emergency needs"}

We are, in principle, heartened to see that the Draft Regulations attempt to implement the Republic's right under the Act to "use or have the intellectual property used throughout the world for the health, security and emergency needs of the Republic" on a royalty free basis (s. 11(1)(e)). However, the specific wording of the relevant provisions of the Draft Regulations will unduly limit the Republic's ability to invoke its rights under the Act.

To begin, the Draft Regulations actually state that the Republic must identify a "specific health, security, and other emergency need" in order for the rights under s. 11(1)(e) of the Act can be invoked (Reg. 8(8)). We share UAEM's concern that this seemingly slight alteration in wording could be interpreted in a manner that significantly narrows the scope of s. 11(1)(e) of the Act. Whereas the Act states that the Republic may invoke its right to a royalty-free license to utilize intellectual property to address a health need, a security need, or another type of emergency, the Draft Regulations appear to collapse these three categories of need into one.

More worrisome, this change in wording coupled with another pre-condition codified in Reg. 8(8)(a) - that "the State must determine the ability of a recipient or any third parties licensed to commercialise the intellectual property, to meet the specific health, security and other emergency need of the public" - will significantly fetter the State's authority to invoke its right under s. 11(1)(e) of the Act.

The rationale for this claim derives from the troubled history of a comparable provision in the Bayh-Dole Act. Like s. 11(1)(e) of the Act, the United States's Bayh-Dole Act reserves so-called "march-in" rights for the government under certain circumstances. ${ }^{14}$ However, despite a number of petitions that presented strong cases for the government to

\footnotetext{
${ }^{11}$ The NIH Best Practices encourage research institutions to: "reserve in their license agreements the right to use the licensed technologies for their own research and educational uses, and to allow other non-profit institutions to do the same."

${ }^{12}$ See Organisation for Economic Co-operation and Development, Guidelines for the Licensing of Genetic Inventions (2006), http://www.oecd.org/dataoecd/39/38/36198812.pdf.

${ }^{13}$ See Stanford University, In the Public Interest: Nine Points to Consider in Licensing University Technology, http://news-service.stanford.edu/news/2007/march7/gifs/whitepaper.pdf; see also, Lori Pressman et al., The licensing of DNA patents by US academic institutions: an empirical survey, 24:1 NATURE BIOTECHNOLOGY 31 (2006).

${ }^{14}$ There are two primary provisions that may trigger march-in rights: (1) where the contractor or assignee "has not taken, or is not expected to take within a reasonable time, effective steps to achieve practical application of the subject invention," or (2) "to alleviate health or safety needs which are not reasonably satisfied by the contractor, assignee, or their licensees." See 35 U.S.C. § 203.
} 
invoke its march-in rights in the name of the public interest, all of the petitions were denied. ${ }^{15}$ We are therefore particularly concerned that the revised wording of the Draft Regulations together with the pre-condition set out in Reg. 8(8)(a) could impose even greater restrictions on the Republic's right to use licensed intellectual property. Based on global disputes concerning some slightly analogous language in international agreements, we can envision debates concerning when a "health" issue would be sufficient to invoke this provision, as well as what constitutes an adequate "emergency."

In short, we believe that the state should be granted broad discretion in this area since the state has a sovereign interest in governing the health and well-being of its citizens. Specific language is provided in the following recommendation section.

\section{B. Our Recommendations}

Given our concerns, we suggest that the following changes be made to the Draft Regulations:

- Modify Reg. 2(1) to clarify that intellectual property can, in certain circumstances, detract from rather than contribute to the socio-economic goals of the Republic, for example, by making subsequent research and access to technologies more inefficient and expensive. A possible rewording of Reg. $2(1)(b)$ that reflects this would be as follows: "whether the intellectual property is more likely to contribute to or undermine the socio-economic goals of the Republic."

- $\quad$ Modify Reg. 2(5) to add the following provision (g):

o "any harm that might be suffered by the Republic if such intellectual property is owned and protected by the recipient or the State"

- Modify Reg. 2(12) to allow recipients to place intellectual property in the public domain regardless of whether it is through an "open-source system." In our view, the term open-source is difficult to define and, more importantly, for the reasons expressed above, there are circumstances in which outright dedication to the public domain is appropriate.

\footnotetext{
${ }^{15}$ However, scholars have suggested that there are adequate grounds for granting march-in rights in such circumstances. E.g., Peter S. Arno \& Michael H. Davis, Why Don't We Enforce Existing Drug Price Controls? The Unrecognized and Unenforced Reasonable Pricing Requirements Imposed upon Patents Deriving in Whole or in Part from Federally Funded Research, 75 TUL. L. REV. 631, 659-67 (2001); Jerome H. Reichman, Testimony Before NIH Public Hearing on March-in Rights under the Bayh-Dole Act (May 25, 2004), http://essentialinventions.org/drug/nih05252004/ (last visited Feb. 25, 2005).

${ }^{16}$ For example, the Trade Related Agreement on Intellectual Property Rights, more commonly known as "TRIPS" clearly provides nations with the ability to issue compulsory licenses of patents without first attempting to negotiation with the patent owner in the case of a national emergency. See TRIPS art. 31(b). However, what constitutes an adequate emergency has been repeatedly called into question. Some have suggested that emergencies are only appropriate where there is an epidemic involving a contagious disease. Similarly, we worry that the wording of the Draft Regulations may be interpreted in a narrow fashion by certain groups.
} 
- Further, recipients should be able to avail of this provision in two different types of situations, one of which would be subject to review by NIPMO whereas the other would not:

- In the first situation, when a recipient determines that the information/intellectual property in question amounts to a fundamental discovery and/or does not require significant subsequent investment in order to be brought to practical application, the recipient should have absolute discretion to release that information/discovery/intellectual property into the public domain without review by NIPMO.

- In the second situation, where the information/intellectual property does not amount to a fundamental discovery and/or may require additional investment before it can be brought to practical application, the recipient may nevertheless elect not to seek intellectual property protection but subject to review by NIPMO.

- The following two revised version of Reg. 2(12) takes into account these changes:

- "In a specific case where a recipient does not wish to protect intellectual property governed by the Act because it wants to place such intellectual property in the public domain, the recipient should assess whether the intellectual property is a fundamental discovery and/or does not require significant additional investment in order to be brought to practical application. If either is the case, the recipient should so state in the prescribed Form IP1 and the NIPMO will not further review whether to seek protection."

- Modify Reg. 2(13) in order to take into account the changes to Reg. 2(12), specifically, by removing the phrase "through open-source systems" from provision (a).

- Also, the wording of Reg. 2(13) should be clarified to reflect the fact that not all factors will be relevant in all cases and thus recipients will be required to explain to NIPMO what factors it considers most important. In particular, a revised version of Reg. 2(13) could read as follows:

- "When making the application under sub-regulation (12), a recipient will be required to demonstrate to NIPMO the extent to which the following considerations are impacted by the intellectual property ...."

- Alter Reg. 2(14)(b) slightly as follows:

○ "where the intellectual property has commercial potential, NIPMO must consider whether issuing one or more royalty free research licenses to other scientific organizations, including international organizations, would provide equivalent access to the relevant organizations as placing the intellectual property in the public domain while not unduly depriving the people of the Republic any economic rewards associated with the development of new services and products." 
- $\quad$ Add the following provision (f) to Reg. 2(14):

$\circ$ "all of the evidence shown by the recipient under 2(13) regarding the benefits potentially associated with placing the information/intellectual property in the public domain"

- All of the Draft Regulations relating to licensing or other transactions (e.g. assignment) of intellectual property, whether domestic or offshore, exclusively or non-exclusively, should be subject to one caveat; namely, that the recipient reserve the right to utilize the intellectual property for academic research and teaching purposes and to transfer that right to other higher education institutions.

o For example, Reg. 8(1) should therefore be revised to read as follows: "Subject to 'Reg. X,' a recipient may at its sole discretion determine the terms and conditions for any non-exclusive license in the Republic..." A 'Reg. X' stating that "the recipient is, in all circumstances, deemed to have reserved the right to practice the intellectual property for academic research and educational purposes and may at any time transfer that right to other higher education institutions" would therefore need to be added to the Draft Regulations.

- The Draft Regulations should be amended to safeguard against possible abuse of intellectual property rights generated through publicly funded research. For example, in the United States, a recipient of federal funding abruptly raised the price of an HIV medication by $400 \%$, the recipient was commercializing the invention, but the price increase made the publicly funded invention out of reach for many citizens; a petition to seek march-in rights for broader access failed because the government funding body determined that there was no statutory authority to invoke its march-in rights in response to the price hike. ${ }^{17}$ To avoid such a situation, we believe that the condition for permitting the state to exercise its rights should be amended as follows:

- 8(8)(a) Before any proclamation by Parliament, the State must determine the ability of a recipient or any third parties licensed to commercialise the intellectual property, to meet the specific health, security and other emergency need of the public without imposing an undue financial burden on the State.

- Finally, in order to ensure that NIPMO is well positioned to address the various issues likely to arise under the Act and Draft Regulations and balance the various interests at stake, we believe it is important to ensure that the Advisory Board contemplated by the Draft Regulations should be composed of individuals with diverse backgrounds and expertise. Specifically, we believe that it is critical that

\footnotetext{
${ }^{17}$ See Elias A. Zerhouni, National Institutes of Health, Determination in the Case of Petition of Essential Inventions 5-6 (July 29, 2004), available at http://www.ott.nih.gov/policy/March-in-norvir.pdf. In another case, the FDA specifically noted that it felt drug prices were irrelevant. Elias A. Zerhouni, National Institutes of Health, Determination in the Case of Petition of Xalantan (Sept. 17, 2004), http:// ott.od.nih.gov/NewPages/xalatan.pdf (last visited Feb. 25, 2005).
} 
the Advisory Board be comprised not only of individuals with expertise in intellectual property law and commercializing technologies, but also with individuals with expertise in public health, medicine, information management, as well as other potentially relevant fields (sociologists with expertise around scientific research).

- Accordingly, Reg. 4(7) should be revised to read that the "Advisory Board should be composed of individuals with diverse experiences and perspectives related to scientific research, public health, law and technology development."

Thank you for the opportunity to comment on the Draft Regulations. We would be pleased to discuss our recommendations or provide further explanation at your request.

Sincerely,

Matt Herder/s/

Matthew Herder

Visiting Professor

matthewherder@stanfordalumni.org
Cynthia \#a/s/

Cynthia Ho

Vickrey Research Professor

cynthiamho@gmail.com 